\title{
The Role of a Software Product Manager in Various Business Environments
}

\author{
Olga Springer, Jakub Miler \\ Gdansk University of Technology \\ Faculty of Electronics, Telecommunications and Informatics \\ 11/12 Narutowicza St., 80-233, Gdansk, Poland \\ Email: \{olga.springer, jakub.miler\}@pg.edu.pl
}

\begin{abstract}
The aim of the paper is to identify the role of the software product manager depending on the size of the company and the characteristics of the product they are working on. This has been achieved in cooperation with 15 experts from the IT industry. The companies were divided into 4 levels of size: micro-enterprises, small businesses, medium businesses and large enterprises. The characteristics of the products were divided into business-business (B2B) and business-customer (B2C). This way, 8 personas of software product managers have been developed. Differences in this role were mainly related to the staffing, its scope of responsibility, tools and techniques used as well as the mode of work with the target customers. Many common aspects of this role have also been identified that made it possible to define archetype persona of a software product manager. All personas have been validated by experts who offered their improvements.
\end{abstract}

\section{INTRODUCTION}

$\mathrm{M}$ ARKETING definition of "a product" is: "a product is anything that can be offered to a market for attention, acquisition, or consumption that might satisfy a want or need" [1]. Since 2007, it is known that systematic product management increases the success rate of software projects [2]. Product management responsibilities are crucial in software companies, as they support decision making process and developing products according to the company strategy. By definition, product management is different from project management, however in many software companies the roles of product manager and project manager are mixed [1].

Similarly to project managers, the product managers must have high level management skills, as very often they lead teams, projects or even departments [3]. Communications skills are important in order to efficiently manage stakeholders and cooperate with development teams to execute product roadmap [1]. The approach to product management often follows the principles of lean management as in the Lean Start-up method [4]. Product managers design and verify the business models in the market [5] with various techniques and tools [6].

This work was supported by DS Funds of ETI Faculty, Gdansk University of Technology.
Product management spans the entire product-life cycle: strategy, concept, market entry and development, evolution [7]. Product managers do not only follow the product-life cycle, they own it. They are responsible for the success of the product, which require them to take care of wide technical and business activities: product strategy, product planning, strategic management, orchestration of the organization's functional areas [1]. It is difficult to start career as a product manager without experience in adjacent disciplines, e.g. marketing or development [8].

There is a role defined in Scrum that is responsible for requirements and business value - the Product Owner [9]. Spectrum of activities and responsibilities of the product manager is much wider than the Product Owner role [10]. Depending on the organization's size, the product manager and the Product Owner roles may be separated or a product manager can assume the Product Owner role, however "in most environments, it makes more sense to have the two roles product owner and product manager separated" [1]. Additionally, earlier research has shown that the approach to projects is related to the business environment [11], [12].

The goal of our research was to understand the current role of product managers in software companies. To achieve this goal, 3 research questions were stated: (RQ1) What is the software product manager's role depending on the company size and characteristics of the product? (RQ2) What are the differences in the role of a software product manager depending on the company size and product type? (RQ3) What are the common characteristics of a software product manager independent of the company size and product type?

The contribution of this paper is the identification of the characteristics of the software product manager's role in different business environments as well as the elaboration of the archetype of this role based on the elements common to all environments.

The paper is organized as follows. Section II discusses the work of other researchers to which we relate our study. Section III describes the research method, the experts and techniques. Section IV provides the personas of product managers specific to different business environments as well 
as the archetype common to all environments. Section V presents the two phase validation of the proposed personas and archetype. Section VI discusses the threats to the validity of this research followed by the conclusions in Section VII.

\section{RELATED WORK}

In 2013, research on software product management was conducted in Lappenranta University of Technology, and its main research question was: which common roles do software product manager fulfill in the organizations? The result of the research is a framework that reveals the role of product managers. Four stereotypical roles were identified in the studied organizations: experts, strategists, leaders and problem solvers [8].

An expert is a person who has a deep expertise in some specialization (e.g. marketing or development), but does not have the responsibility for product management activities. It is a kind of informal product manager, who works close to product and knows it very well. He is involved in the implementation to decide on feature priorities. The strategist is a product manager who has an impact on the company product vision and roadmap. As the authority of the strategist grows, he becomes the third profile, the leader, who has access to product resources and can manage it. The fourth profile is the problem solver who manages stakeholders and resolves product-related issues, but it is the management who defines the strategy and roadmaps [8].

The framework was developed empirically based on interviews with companies' representatives and by researching the documentation. Besides the framework mentioned, super categories with properties were also identified based on the grounded theory [21] analysis:

- access to resources - ownership of the product budget, possibility to hire people, information resources,

- influence on the product - orchestration of development, definition of tactical actions, participation in strategy planning, creation of roadmaps,

- authority - product leadership, power of decision making,

- influence on collaboration - ability to resolve problems between departments, level of communication.

In 2014, Christof Ebert and Sjaak Brinkkemper defined product management key success factors, their effect on business and challenges that stand ahead of the product management [13]. They also described 4 best practices for systematic product management. They stated that during the research the majority of product managers that have been found in software companies had: "a strong technical background and rather weak finance, marketing and general management skills" [13].

"Software Product Management" book, published in 2017 by H. Bernand Kittlaus and Samuel A. Fricker [1] is a review of software product management and many terms related to it like: management of software as a business, product strategy, product planning, strategic management, orchestration of the organization's functional areas. It also introduces the Software Product Management Framework, which is an integration and consolidation of three other frameworks that were invented:

- Reference Framework for Software Product Management developed by Inge van de Weerd, Willem Bekkers, Sjaak Brinkkemper, and colleagues at the University of Utrecht, Netherlands in 2006 [14]. This framework describes the core activities of a software product manager in specific areas: portfolio management, product planning, release planning, requirements management.

- Pragmatic Marketing Framework developed by Kittlaus and Clough [15] that describes the aspects of product management, product marketing and defines the role a of product manager and product marketing manager ultimately.

- a paper by Ebert on the impacts of software product management [2], a proposal on how to manage software along the product lifecycle phases.

Software Product Management Framework indicates the main functional areas of a software organization: strategic management, product strategy, product planning, development, marketing, sales and distribution, service and support. Each area has related activities assigned.

Product management is gaining popularity every year, however it has been topic for a scientific research only few times in the recent years. Of 3 researches on software product management described above only one of them is focusing strictly on the product manager's role, however it does not analyze if this role depends on the company size and product type.

\section{RESEARCH METHOD}

Our research was carried out as a qualitative study using grounded theory [21] as a research method. The identification of the role of the software product manager has been achieved in cooperation with 10 experts with more than 2 years of experience in research and business projects in the IT industry. The experts worked as:

- a product manager,

- an employee with product management responsibilities but named differently,

- an employee working in close cooperation with a product manager.

The companies were divided into 4 levels of size (ranged in size of number of employees): micro-enterprises (1-10), small businesses (10-50), medium businesses (50-250) and large enterprises $(250+)$ [16]. The characteristics of the products were divided according to the product delivery model into business-business (B2B) and business-customer (B2C) [17]. Combining these dimensions, we analyzed the software product manager's role in 8 different environments. The characteristics of the experts are presented in Table I. 
TABLE I.

CHARACTERISTICS OF THE INTERVIEWED EXPERTS

\begin{tabular}{|c|c|c|c|c|}
\hline Identifier & Position & Company & Size & $\begin{array}{c}\text { Delivery } \\
\text { model }\end{array}$ \\
\hline E1 & $\begin{array}{l}\text { Vicepresident } \\
\text { of Projects }\end{array}$ & UXpin & $\begin{array}{l}\text { medium, } \\
\text { large }\end{array}$ & $\begin{array}{l}\text { B2B, } \\
\text { B2B, B2C }\end{array}$ \\
\hline E2 & Vicepresident & $\begin{array}{l}\text { Rocket } \\
\text { Studio }\end{array}$ & $\begin{array}{l}\text { large, } \\
\text { large }\end{array}$ & $\mathrm{B} 2 \mathrm{~B}, \mathrm{~B} 2 \mathrm{C}$ \\
\hline E3 & $\begin{array}{l}\text { Product } \\
\text { manager }\end{array}$ & Spartez & $\begin{array}{l}\text { medium, } \\
\text { large }\end{array}$ & $\begin{array}{l}\mathrm{B} 2 \mathrm{C}, \\
\mathrm{B} 2 \mathrm{~B}\end{array}$ \\
\hline E4 & President & $\begin{array}{l}\text { RoomAuction } \\
\text {.com Ltd. }\end{array}$ & $\begin{array}{l}\text { micro, } \\
\text { small }\end{array}$ & $\mathrm{B} 2 \mathrm{~B}, \mathrm{~B} 2 \mathrm{C}$ \\
\hline E5 & $\begin{array}{l}\text { Product } \\
\text { manager }\end{array}$ & $\begin{array}{l}\text { Better } \\
\text { Solutions }\end{array}$ & small & B2B \\
\hline E6 & $\begin{array}{l}\text { Business } \\
\text { analyst }\end{array}$ & Net PC & small & B2B \\
\hline E7 & $\begin{array}{l}\text { Product } \\
\text { manager }\end{array}$ & AirHelp & medium & B2C \\
\hline E8 & $\begin{array}{l}\text { Project } \\
\text { manager }\end{array}$ & dr Poket & micro & B2C \\
\hline E9 & $\begin{array}{l}\text { Product } \\
\text { manager }\end{array}$ & $\begin{array}{l}\text { Young } \\
\text { Digital Planet }\end{array}$ & large & B2C \\
\hline E10 & $\begin{array}{l}\text { Product } \\
\text { manager }\end{array}$ & AirHelp & $\begin{array}{l}\text { micro, } \\
\text { small }\end{array}$ & $\begin{array}{l}\mathrm{B} 2 \mathrm{C} \\
\mathrm{B} 2 \mathrm{C}\end{array}$ \\
\hline
\end{tabular}

We have used the technique of a persona [18] to describe the identified roles of a software product manager. This technique aims at building a profile of a representative member of a particular group of people. Such profile may include various attributes. Based on our research goals and the literature we have selected a set of attributes of the software product manager's role and taken them as the model of our personas. This model with the description of all the attributes is presented in Table II. Further in the research, this model was used to define 8 personas of product managers from various business environments.

The main instrument of the data collection were the structured interviews with experts conducted in the form of face to face meetings in May 2016. We have asked the experts the following questions based on the persona model:

- What is your experience in product management area?

- How many years you have been working as product manager or as related role?

- Who else was responsible for product management?

- What were the goals and responsibilities of product managers?

- What was the product lifecycle?

- Who did you cooperate with?

- What techniques did you use?

- What tools did you use?

- What are the first steps to become a product managers? How in your opinion young people interested in this path of career can get first experience?
TABLE II.

A MODEL OF A SOFTWARE PRODUCT MANAGER'S PERSONA

\begin{tabular}{|c|c|}
\hline Attribute & Description \\
\hline $\begin{array}{l}\text { Introduction to } \\
\text { the environment }\end{array}$ & $\begin{array}{l}\text { The specificity of the environment and its approach } \\
\text { to product management. }\end{array}$ \\
\hline Objectives & $\begin{array}{l}\text { The objectives of the Product Manager or the role } \\
\text { with his responsibilities, depending on the size of } \\
\text { the organization. }\end{array}$ \\
\hline Responsibilities & $\begin{array}{l}\text { The responsibilities of the Product Manager's role, } \\
\text { depending on the size of the organization. }\end{array}$ \\
\hline $\begin{array}{l}\text { Product Life } \\
\text { Cycle }\end{array}$ & $\begin{array}{l}\text { The development phases of the product, on which } \\
\text { the approach to project management depends. }\end{array}$ \\
\hline $\begin{array}{l}\text { Main } \\
\text { competences }\end{array}$ & $\begin{array}{l}\text { The required competences of product managers } \\
\text { including soft and hard skills. }\end{array}$ \\
\hline $\begin{array}{l}\text { Cooperation } \\
\text { with other teams }\end{array}$ & $\begin{array}{l}\text { Teams and roles that product manager cooperates } \\
\text { with. }\end{array}$ \\
\hline $\begin{array}{l}\text { Roles in the } \\
\text { product team }\end{array}$ & $\begin{array}{l}\text { The location of the product team within the } \\
\text { organization and its characteristics. }\end{array}$ \\
\hline Techniques & $\begin{array}{l}\text { List of techniques used by the product manager } \\
\text { including techniques for: verification of the product } \\
\text { vision and strategy, product delivery management, } \\
\text { user research. }\end{array}$ \\
\hline Tools & $\begin{array}{l}\text { List of tools used by the product manager to: } \\
\text { manage tasks and backlog, user research, store } \\
\text { documentation, prototype and collaborate with } \\
\text { other roles. }\end{array}$ \\
\hline First steps & $\begin{array}{l}\text { Career opportunities as a product manager and } \\
\text { specific steps that can be taken to become a } \\
\text { product manager. }\end{array}$ \\
\hline Other positions & $\begin{array}{l}\text { Other positions or roles responsible for product } \\
\text { management. }\end{array}$ \\
\hline
\end{tabular}

Each interview lasted from 30 to 60 minutes and was recorded, analyzed, and documented. The recordings allowed to fill up the model properly with the data. The templates for the interviews were filled by the researcher, however later on they were validated by every expert (see section IV). Many interviewed experts provided insights to more than one business environment as a result of their experience. The coverage of the analyzed business environments with the interviews is presented in Table III.

TABLE III.

NUMBER OF INTERVIEWS FOR EACH COMPANY SIZE AND DELIVERY MODEL

\begin{tabular}{|l|c|c|}
\hline Size / Delivery model & B2B & B2C \\
\hline micro & 1 & 2 \\
\hline small & 2 & 2 \\
\hline medium & 1 & 2 \\
\hline large & 3 & 3 \\
\hline
\end{tabular}

Additionally, we aimed at the identification of the most inherent aspects of the software product manager's role which seem independent from the business environment. To capture this viewpoint we employed the concept of an archetype which is a common recurring motif or pattern assumed to represent fundamental characteristics of a thing [19]. We have built an archetype of a software product 
manager which can be viewed as a super-persona, a more general or abstract persona than the personas specific to different business environments (in object-oriented modeling the archetype would be a superclass of the classes of specific personas, hence the name super-persona).

The software product manager's archetype was built using the following rules: (1) include common elements that repeat in each specific persona; (2) find a classification or a generalization of elements that do not repeat directly in the specific personas; (3) include the classes or generalization of elements identified by rule 2. Considering each specific persona as a set of values of the attributes, the resulting archetype can be considered an intersection of these personas focusing on their commonalities.

TABLE IV.

SOFTWARE PRODUCT MANAGER IN A MICRO-ENTERPRISE, B2C

\begin{tabular}{|c|c|}
\hline Attribute & Description \\
\hline $\begin{array}{l}\text { Introduction to } \\
\text { the environment }\end{array}$ & $\begin{array}{l}\text { Responsibility for the product management and all } \\
\text { tasks associated with the role of product manager } \\
\text { are handled by the company's founders. Generally } \\
\text { there is no strict product manager position. }\end{array}$ \\
\hline Objectives & $\begin{array}{l}\text { To recognize customer needs and develop a valid } \\
\text { business model }\end{array}$ \\
\hline Responsibilities & $\begin{array}{l}\text { Project management, prototype development } \\
\text { (MVP), team-building, tasks related to marketing } \\
\text { and sales, gathering users' feedback, fund } \\
\text { gathering, resource management. }\end{array}$ \\
\hline $\begin{array}{l}\text { Product Life } \\
\text { Cycle }\end{array}$ & $\begin{array}{l}\text { Idea, business model verification, introducing } \\
\text { functional prototype to the market, sales and } \\
\text { product development, maturity, decline. Different } \\
\text { approach to product management depending on the } \\
\text { phase. }\end{array}$ \\
\hline $\begin{array}{l}\text { Main } \\
\text { competences }\end{array}$ & $\begin{array}{l}\text { Understanding of the problem domain, cooperation } \\
\text { skills, openness, communication skills, } \\
\text { entrepreneurship, visionary, priority management. }\end{array}$ \\
\hline $\begin{array}{l}\text { Cooperation } \\
\text { with other teams }\end{array}$ & $\begin{array}{l}\text { Mutual cooperation of the company's founders } \\
\text { (partners), cooperation with the development team } \\
\text { (internal or external), cooperation with mentors and } \\
\text { investors, cooperation with external entities (i.e. } \\
\text { design agency) }\end{array}$ \\
\hline $\begin{array}{l}\text { Roles in the } \\
\text { product team }\end{array}$ & $\begin{array}{l}\text { Multidisciplinary team of several people with } \\
\text { different competences. }\end{array}$ \\
\hline Techniques & $\begin{array}{l}\text { Business Model Canvas, Product Roadmap, } \\
\text { Product Backlog, Agile techniques, Personas, } \\
\text { Product Map, Statistical analytics, Workshops with } \\
\text { end users, Usability labs, Prototyping }\end{array}$ \\
\hline Tools & $\begin{array}{l}\text { Podio, Trello, Mixpanel (free version), Google } \\
\text { Analitycs, Microsoft Office, Physical board, Posts- } \\
\text { its }\end{array}$ \\
\hline First steps & $\begin{array}{l}\text { Learn the company, the product specifics and the } \\
\text { users' needs e.g. while working in customer support } \\
\text { team or at a technical position. }\end{array}$ \\
\hline Other positions & $\begin{array}{l}\text { Chief Executive Officer (CEO), Analyst, Project } \\
\text { Manager, Developer }\end{array}$ \\
\hline
\end{tabular}

\section{RESULTS}

This section presents the proposed personas of software product managers depending on the business environment (the organization size and the product delivery model), initial observations on the differences of the product manager's role among business environments as well as the final superpersona of an archetypical software product manager. The section follows the increasing company size. Sections A, B, $\mathrm{C}$, and D are related to RQ1, section E to RQ2 and section F to RQ3.

\section{A. Micro-enterprises}

The personas of a software product manager in a microenterprise are presented in Table IV (B2C delivery model) and Table V (B2B delivery model). It could be observed that in the companies of this size the product manager's role is not assigned to a distinct post but is rather fulfilled by the company owner or the CEO.

TABLE V.

SOFTWARE PRODUCT MANAGER IN A MICRO-ENTERPRISE, B2B

\begin{tabular}{|c|c|}
\hline Attribute & Description \\
\hline $\begin{array}{l}\text { Introduction to } \\
\text { the environment }\end{array}$ & $\begin{array}{l}\text { Responsibility for the product management and all } \\
\text { tasks associated with the role of product manager } \\
\text { are handled by the company's founders. Generally } \\
\text { there is no strict product manager position. }\end{array}$ \\
\hline Objectives & $\begin{array}{l}\text { To recognize customer needs and develop a valid } \\
\text { business model }\end{array}$ \\
\hline Responsibilities & $\begin{array}{l}\text { Project management, creating the product strategy, } \\
\text { setting the short-term goals, coordinating work to } \\
\text { achieve the goals, market research, tasks related to } \\
\text { marketing and sales, acquiring knowledge from } \\
\text { experienced "business sharks", establishing } \\
\text { relationships and networking with prospecting } \\
\text { clients, gathering customer feedback, business } \\
\text { analytics, close cooperation with the founders. }\end{array}$ \\
\hline $\begin{array}{l}\text { Product Life } \\
\text { Cycle }\end{array}$ & $\begin{array}{l}\text { Idea, business model verification, introducing } \\
\text { functional prototype to the market, sales and } \\
\text { product development. Different approach to } \\
\text { product management depending on the phase. }\end{array}$ \\
\hline $\begin{array}{l}\text { Main } \\
\text { competences }\end{array}$ & $\begin{array}{l}\text { Consistency and persistence, data analysis and } \\
\text { synthesis, understanding customer needs, soft } \\
\text { skills, flexibility, inquisitiveness, openness and the } \\
\text { ability to establish business contacts. }\end{array}$ \\
\hline $\begin{array}{l}\text { Cooperation } \\
\text { with other teams }\end{array}$ & $\begin{array}{l}\text { Mutual cooperation of the company's founders } \\
\text { (partners), cooperation with the development team } \\
\text { (internal or external), cooperation with mentors and } \\
\text { investors. }\end{array}$ \\
\hline $\begin{array}{l}\text { Roles in the } \\
\text { product team }\end{array}$ & $\begin{array}{l}\text { Multidisciplinary team of several people with } \\
\text { different competences. }\end{array}$ \\
\hline Techniques & $\begin{array}{l}\text { Business Model Canvas, Product Roadmap, Product } \\
\text { Backlog, Agile techniques, Personas, Workshops } \\
\text { with clients, Usability tests, Web analytics, }\end{array}$ \\
\hline Tools & $\begin{array}{l}\text { Asana, MindMaster, Trello, Slack, Skype, MS } \\
\text { Office, Physical board, Posts-its }\end{array}$ \\
\hline First steps & $\begin{array}{l}\text { Read a lot, create something of your own or start a } \\
\text { career in technical positions. }\end{array}$ \\
\hline Other positions & Chief Executive Officer (CEO), founders, president \\
\hline
\end{tabular}

\section{B. Small enterprises}

The personas of a software product manager in a small enterprise are presented in Table VI (B2C delivery model) and Table VII (B2B delivery model). It could be observed that the companies of this size start to hire the product manager as a distinct post. 
TABLE VI.

SOFTWARE PRODUCT MANAGER IN A SMALL ENTERPRISE, B2C

\begin{tabular}{|c|c|}
\hline Attribute & Description \\
\hline $\begin{array}{l}\text { Introduction to } \\
\text { the environment }\end{array}$ & $\begin{array}{l}\text { Responsibility for the product management is on } \\
\text { the founders of the company. At some point, the } \\
\text { Product Manager is hired to support the founders. }\end{array}$ \\
\hline Objectives & $\begin{array}{l}\text { Co-creation and execution of the product strategy, } \\
\text { support in defining the company's business goals. }\end{array}$ \\
\hline Responsibilities & $\begin{array}{l}\text { Product development, incremental product } \\
\text { delivery, negotiation of priorities with the } \\
\text { stakeholders, prototyping, cooperation with } \\
\text { external suppliers, solving users' problems. }\end{array}$ \\
\hline $\begin{array}{l}\text { Product Life } \\
\text { Cycle }\end{array}$ & $\begin{array}{l}\text { Idea, introduction to the market, growth, maturity, } \\
\text { decline. Very high work dynamics in the phases of } \\
\text { introduction and growth. Different approach to } \\
\text { product management depending on the phase. }\end{array}$ \\
\hline $\begin{array}{l}\text { Main } \\
\text { competences }\end{array}$ & $\begin{array}{l}\text { Project management, data analysis, ability to work } \\
\text { in a dynamic environment, communication, } \\
\text { negotiations, empathy. }\end{array}$ \\
\hline $\begin{array}{l}\text { Cooperation } \\
\text { with other teams }\end{array}$ & $\begin{array}{l}\text { Cooperation with the founders, project manager, } \\
\text { customer support, and development team. }\end{array}$ \\
\hline $\begin{array}{l}\text { Roles in the } \\
\text { product team }\end{array}$ & $\begin{array}{l}\text { A multidisciplinary team: product manager, project } \\
\text { manager, graphic/UX designer. }\end{array}$ \\
\hline Techniques & $\begin{array}{l}\text { NPS (net promoter score), product roadmap, } \\
\text { product backlog, agile techniques, user stories, } \\
\text { interviews, prototyping. }\end{array}$ \\
\hline Tools & $\begin{array}{l}\text { Trello, Google Analitycs, Mixpanel, Skype, Axure, } \\
\text { Gdrive }\end{array}$ \\
\hline First steps & $\begin{array}{l}\text { Begin a career in the development environment, for } \\
\text { example as a project manager, tester, or developer. } \\
\text { Observe the product development process and get } \\
\text { to know the product. Observe and learn from } \\
\text { experienced product managers. }\end{array}$ \\
\hline Other positions & $\begin{array}{l}\text { Chief Executive Officer (CEO), founders, } \\
\text { president, Chief Technology Officer (CTO), Chief } \\
\text { Marketing Officer (CMO), project manager. }\end{array}$ \\
\hline
\end{tabular}

TABLE VII.

SOFTWARE PRODUCT MANAGER IN A SMALL ENTERPRISE, B2B

\begin{tabular}{|l|l|}
\hline \multicolumn{1}{|c|}{ Attribute } & \multicolumn{1}{c|}{ Description } \\
\hline $\begin{array}{l}\text { Introduction to } \\
\text { the environment }\end{array}$ & $\begin{array}{l}\text { There is or there is not a defined role of the Product } \\
\text { Manager depending on the relationship with the } \\
\text { client. In the latter case, the roles that share the } \\
\text { responsibility for product management are Project } \\
\text { Manager and Business Analyst. }\end{array}$ \\
\hline Objectives & $\begin{array}{l}\text { Co-creation and implementation of the business } \\
\text { goals of the company, delivering the product to the } \\
\text { customer according to the requirements. }\end{array}$ \\
\hline Responsibilities & $\begin{array}{l}\text { Defining, clarifying and specifying the } \\
\text { requirements, contacting the client, prototyping of } \\
\text { interfaces, prioritizing tasks according to the } \\
\text { client's needs, proposing solutions, building } \\
\text { customer relations, examining customer needs. }\end{array}$ \\
\hline $\begin{array}{l}\text { Product Life } \\
\text { Cycle }\end{array}$ & $\begin{array}{l}\text { If company offer universal product for all b2b } \\
\text { customers: Idea, introduction to the market, } \\
\text { growth, maturity, decline. If company offers } \\
\text { custom solutions for enterprises: Tender } \\
\text { specification, cost valuation stage, bidding, } \\
\text { product implementation (or its development, } \\
\text { maintenance), closing the project. Permanent } \\
\text { cooperation with the client is also possible. } \\
\text { Different approach to product management }\end{array}$ \\
\hline
\end{tabular}

\begin{tabular}{|l|l|}
\hline & depending on the phase. \\
\hline $\begin{array}{l}\text { Main } \\
\text { competences }\end{array}$ & $\begin{array}{l}\text { Analytical thinking, accuracy, project management, } \\
\text { communication skills, decision-making, } \\
\text { negotiations, empathy and understanding of } \\
\text { customer needs, forming business relationships. }\end{array}$ \\
\hline $\begin{array}{l}\text { Cooperation } \\
\text { with other teams }\end{array}$ & $\begin{array}{l}\text { Cooperation with project manager, business analyst } \\
\text { customer support, and designers }\end{array}$ \\
\hline $\begin{array}{l}\text { Roles in the } \\
\text { product team }\end{array}$ & $\begin{array}{l}\text { A multidisciplinary team: product manager, project } \\
\text { manager, business analyst, graphic/UX designer. }\end{array}$ \\
\hline Techniques & $\begin{array}{l}\text { Product backlog, product roadmap, use cases, } \\
\text { wireframes, UML diagrams, interviews, workshops } \\
\text { with clients, project plan, requirements } \\
\text { specification. }\end{array}$ \\
\hline Tools & $\begin{array}{l}\text { Jira, Mantis, Axure, Proto.io, UXPin, Balsamiq, } \\
\text { Enterprise Architect. }\end{array}$ \\
\hline First steps & $\begin{array}{l}\text { Read about project management and analysis. } \\
\text { Begin a career in the position of: analyst, project } \\
\text { manager, programmer, tester. }\end{array}$ \\
\hline Other positions & Project manager, business analyst. \\
\hline
\end{tabular}

\section{Medium enterprises}

The personas of a software product manager in a medium enterprise are presented in Table VIII (B2C delivery model) and Table IX (B2B delivery model). It could be observed that the companies of this size build product management teams around the product manager.

TABLE VIII.

SOFTWARE PRODUCT MANAGER IN A MEDIUM ENTERPRISE, B2C

\begin{tabular}{|c|c|}
\hline Attribute & Description \\
\hline $\begin{array}{l}\text { Introduction to } \\
\text { the environment }\end{array}$ & $\begin{array}{l}\text { Software companies aware of the need for product } \\
\text { management. Defined role of the Product Manager. }\end{array}$ \\
\hline Objectives & $\begin{array}{l}\text { Defining the product strategy in line with the } \\
\text { company's business goals and its implementation. }\end{array}$ \\
\hline Responsibilities & $\begin{array}{l}\text { Defining the way to achieve company's business } \\
\text { objectives, confirming the expectations of the } \\
\text { stakeholders, communication of results to the } \\
\text { stakeholders, gathering requirements, defining } \\
\text { needs or problems, analyzing numerical data, user } \\
\text { research, refining and describing initiatives, } \\
\text { projects and tasks, confirming priorities with } \\
\text { stakeholders, coordination of project } \\
\text { implementation, communication of initiatives and } \\
\text { reporting of achieved goals after implementation, } \\
\text { cooperation with development team - daily } \\
\text { communication in order to specify requirements, } \\
\text { participation in Scrum meetings (primarily in } \\
\text { planning meetings). }\end{array}$ \\
\hline $\begin{array}{l}\text { Product Life } \\
\text { Cycle }\end{array}$ & $\begin{array}{l}\text { Idea, Introduction, Growth, Maturity, Decline. } \\
\text { Different approach to product management } \\
\text { depending on the phase. }\end{array}$ \\
\hline $\begin{array}{l}\text { Main } \\
\text { competences }\end{array}$ & $\begin{array}{l}\text { Communicativeness, openness, assertiveness, } \\
\text { ability to create visions, analytical mind, } \\
\text { understanding of users' needs. }\end{array}$ \\
\hline $\begin{array}{l}\text { Cooperation } \\
\text { with other teams }\end{array}$ & $\begin{array}{l}\text { Cooperation with: designers, developers, testers, } \\
\text { stakeholders (leaders of other teams i.e. customer } \\
\text { service or sales), management board, other product } \\
\text { managers (often goals and initiatives are shared). }\end{array}$ \\
\hline $\begin{array}{l}\text { Roles in the } \\
\text { product team }\end{array}$ & $\begin{array}{l}\text { The product team consists of: product managers, } \\
\text { designers, user research specialists, conversion } \\
\text { specialists, and translation specialist (multilingual } \\
\text { support for the product). Some competencies may } \\
\text { be outsourced. }\end{array}$ \\
\hline
\end{tabular}




\begin{tabular}{|l|l|}
\hline Techniques & $\begin{array}{l}\text { Product roadmap, user stories, personas, user } \\
\text { research, interviews, wireframes, A/B tests, NPS } \\
\text { (Net Promoter Score), workshops with } \\
\text { stakeholders, story mapping. }\end{array}$ \\
\hline Tools & $\begin{array}{l}\text { Jira, Confluence, Slack, Skype, Proto.io, HotJar, } \\
\text { Google Analitycs, Mixpanel. }\end{array}$ \\
\hline First steps & $\begin{array}{l}\text { Participation in workshops, presentations, trainings } \\
\text { on product management and project management, } \\
\text { individual learning, online courses. Membership in } \\
\text { non-profit organizations to develop soft skills } \\
\text { recommended. Career can be started at another job } \\
\text { position to learn the product and then the change of } \\
\text { the role might be possible. }\end{array}$ \\
\hline Other positions & $\begin{array}{l}\text { Product Owner, brand manager, project manager, } \\
\text { business analyst. }\end{array}$ \\
\hline
\end{tabular}

TABLE IX.

SOFTWARE PRODUCT MANAGER IN A MEDIUM ENTERPRISE, B2B

\begin{tabular}{|l|l|}
\hline \multicolumn{1}{|c|}{ Attribute } & \multicolumn{1}{|c|}{ Description } \\
\hline $\begin{array}{l}\text { Introduction to } \\
\text { the environment }\end{array}$ & $\begin{array}{l}\text { Software companies aware of the need for product } \\
\text { management. Defined role of the Product Manager. }\end{array}$ \\
\hline Objectives & $\begin{array}{l}\text { Defining the product strategy for business } \\
\text { customers, in line with the company's business } \\
\text { goals. }\end{array}$ \\
\hline Responsibilities & $\begin{array}{l}\text { Responsibility for many aspects, both technical and } \\
\text { business, defining product strategy, market } \\
\text { analysis, researching customer needs, creating a } \\
\text { product roadmap, defining product goals, working } \\
\text { close with main executives. }\end{array}$ \\
\hline $\begin{array}{l}\text { Product Life } \\
\text { Cycle }\end{array}$ & $\begin{array}{l}\text { Idea, Introduction, Growth, Maturity, Decline. } \\
\text { Different approach to product management } \\
\text { depending on the phase. }\end{array}$ \\
\hline $\begin{array}{l}\text { Main } \\
\text { competences }\end{array}$ & $\begin{array}{l}\text { Curiosity of the world, data-based analysis, } \\
\text { openness, empathy, understanding people, } \\
\text { leadership skills. }\end{array}$ \\
\hline $\begin{array}{l}\text { Cooperation } \\
\text { with other teams }\end{array}$ & $\begin{array}{l}\text { Cooperation with all departments in the company: } \\
\text { sales, marketing, business development, customer } \\
\text { support, project managers. }\end{array}$ \\
\hline $\begin{array}{l}\text { Roles in the } \\
\text { product team }\end{array}$ & $\begin{array}{l}\text { Product managers are gathered in one operational } \\
\text { team together with designers and user researchers. }\end{array}$ \\
\hline Techniques & $\begin{array}{l}\text { Product roadmap, user research, interviews with } \\
\text { prospects and clients, user recordings, A/B tests. }\end{array}$ \\
\hline Tools & $\begin{array}{l}\text { ProdPad, Target Process, Microsoft Office, } \\
\text { Keynote, UXPin. }\end{array}$ \\
\hline First steps & $\begin{array}{l}\text { Start a career in the software company as } \\
\text { developer, tester, customer support specialist, } \\
\text { project manager. Start your own startup. }\end{array}$ \\
\hline Designer, tech lead, project manager. \\
\hline
\end{tabular}

\section{Large enterprises}

The personas of a software product manager in a large enterprise are presented in Table X (B2C delivery model) and Table XI (B2B delivery model). It could be observed that the companies of this size can employ multiple product managers on the per project or per department basis.

TABLE X.

SOFTWARE PRODUCT MANAGER IN A LARGE ENTERPRISE, B2C

\begin{tabular}{|l|l|}
\hline \multicolumn{1}{|c|}{ Attribute } & \multicolumn{1}{c|}{ Description } \\
\hline $\begin{array}{l}\text { Introduction } \\
\text { to the }\end{array}$ & $\begin{array}{l}\text { In many large enterprises, the role of product manager } \\
\text { is taken by persons from departments within which a }\end{array}$ \\
\hline
\end{tabular}

\begin{tabular}{|c|c|}
\hline environment & $\begin{array}{l}\text { new project is initiated or a product is developed. The } \\
\text { product management is not their only responsibility. } \\
\text { They also perform other duties resulting from the } \\
\text { specificity of their positions. Only some software } \\
\text { companies (mature, product-driven and agile) employ } \\
\text { dedicated product managers who define the product } \\
\text { strategy and roadmap. }\end{array}$ \\
\hline Objectives & $\begin{array}{l}\text { Defining a product strategy in accordance with the } \\
\text { company's business strategy, achieving goals. }\end{array}$ \\
\hline $\begin{array}{l}\text { Responsibili } \\
\text { ties }\end{array}$ & $\begin{array}{l}\text { Defining the scope, contact with stakeholders, } \\
\text { collecting requirements and opinions, receiving } \\
\text { product increments and accepting the work done by the } \\
\text { development team, reporting to the steering committee, } \\
\text { cooperation with the development team (sometimes } \\
\text { this responsibility is transferred to the project } \\
\text { manager), presenting the product inside the company, } \\
\text { acquiring the budget for specific actions, data analysis, } \\
\text { cooperation with roles with different competences } \\
\text { (analyzes, trends, interfaces). }\end{array}$ \\
\hline $\begin{array}{l}\text { Product Life } \\
\text { Cycle }\end{array}$ & $\begin{array}{l}\text { A product is created in a project (initiation, planning, } \\
\text { development, closing phases) or along with the product } \\
\text { idea a project is launched to verify its business value } \\
\text { (concept phase, running an experiment and gathering } \\
\text { feedback from the market, implementation of a } \\
\text { functional prototype, sales and development). Different } \\
\text { approach to product management depending on the } \\
\text { phase." }\end{array}$ \\
\hline $\begin{array}{l}\text { Main } \\
\text { competences }\end{array}$ & $\begin{array}{l}\text { Leadership skills, impact on people despite the lack of } \\
\text { authority, negotiation skills, assertiveness, ability to } \\
\text { prioritize and make decision, business knowledge, } \\
\text { creativity, listening to others, taking criticism, } \\
\text { teamwork skills, useful technical knowledge, } \\
\text { presentation skills, knowledge about techniques and } \\
\text { tools. }\end{array}$ \\
\hline $\begin{array}{l}\text { Cooperation } \\
\text { with other } \\
\text { teams }\end{array}$ & $\begin{array}{l}\text { Cooperation with: development team, project manager, } \\
\text { steering committee, project sponsor, stakeholders, } \\
\text { directors of sales, marketing, and customer support } \\
\text { departments. Cooperation with subcontractors. } \\
\text { Horizontal and vertical communication (reporting to } \\
\text { the board). }\end{array}$ \\
\hline $\begin{array}{l}\text { Roles in the } \\
\text { product } \\
\text { team }\end{array}$ & $\begin{array}{l}\text { Depends on the organization structure. Mainly } \\
\text { multidisciplinary teams working on one product, one } \\
\text { product is one department or division. As part of the } \\
\text { operational team: product manager, project manager, } \\
\text { research specialists, UX experts. Rarely a dedicated } \\
\text { product team, possibly in mature technology } \\
\text { companies that have grown up on product-driven work } \\
\text { (e.g. Atlassian). }\end{array}$ \\
\hline Techniques & $\begin{array}{l}\text { Product roadmap, product backlog, Business Model } \\
\text { Canvas, personas, user research, MindMap, } \\
\text { goRoadmap, interviews and surveys, market trends } \\
\text { analysis, statistical analysis, predictions, correlations. }\end{array}$ \\
\hline Tools & $\begin{array}{l}\text { Google Analytics, Mixpanel, Jira, Jira Portfolio, Asana, } \\
\text { Redmine, Trello, Sharepoint, Confluence, MS Project, } \\
\text { Microsoft Office, Intercom, HotJar, SurveyMonkey. }\end{array}$ \\
\hline First steps & $\begin{array}{l}\text { Learn about techniques, tools, good interface design } \\
\text { practices, learn systematic work e.g. by running a } \\
\text { project. You can start your career as: programmer, } \\
\text { tester, UX designer, analyst, or starting your own } \\
\text { startup. You can also hire as a product manager's } \\
\text { assistant and train under his supervision. Develop } \\
\text { communication skills and work in a group, e.g. by } \\
\text { leading non-profit projects. }\end{array}$ \\
\hline $\begin{array}{l}\text { Other } \\
\text { positions }\end{array}$ & $\begin{array}{l}\text { Project manager, product development manager, } \\
\text { product owner, brand manager, marketing director, } \\
\text { business analyst (in case the product is an in-house } \\
\text { system) }\end{array}$ \\
\hline
\end{tabular}


TABLE XI.

SOFTWARE PRODUCT MANAGER IN A LARGE ENTERPRISE, B2B

\begin{tabular}{|l|l|}
\hline \multicolumn{1}{|c|}{ Attribute } & \multicolumn{1}{c|}{ Description } \\
\hline $\begin{array}{l}\text { Introduction to } \\
\text { the environment }\end{array}$ & $\begin{array}{l}\text { In many large enterprises, the role of product } \\
\text { manager is taken by persons from departments } \\
\text { within which a new project is initiated or a product } \\
\text { is developed. The product management is not their } \\
\text { only responsibility. They also perform other duties } \\
\text { resulting from the specificity of their positions. } \\
\text { Only some software companies (mature, product- } \\
\text { driven and agile) employ dedicated product } \\
\text { managers who define the product strategy. }\end{array}$ \\
\hline Objectives & $\begin{array}{l}\text { Collection of requirements from the customer and } \\
\text { delivery of the ordered product. The Product } \\
\text { Manager the most often has no impact on the } \\
\text { company objectives and product strategy, } \\
\text { implements elements of the company's overall } \\
\text { strategy. }\end{array}$ \\
\hline Responsibilities & $\begin{array}{l}\text { Contact with the client, collecting requirements and } \\
\text { opinions from the clients, cost estimation, } \\
\text { managing the budget, ordering additional resources } \\
\text { (e.g. usability research), proposing solutions, } \\
\text { planning team work, supervising the } \\
\text { implementation, presentation of product increments } \\
\text { to the client, synthesis of a large number of } \\
\text { development threads. Responsibilities depends on } \\
\text { how product manager role is set up - sometimes } \\
\text { product manager doesn't own budget and doesn't } \\
\text { work on any cost estimations. }\end{array}$ \\
\hline Forst
\end{tabular}

\section{E. Differences among business environments}

Our research suggests several differences in the approach to product management and the role of the software product manager depending on the size of the organization. Different roles are responsible for product management in the early stage, the responsibilities are spread between founders and the core team. As the company grows it is more often when dedicated software product manager appear on board. It can also be seen that large companies use more advanced tools and techniques, and often specialized competences are outsourced. Additionally, the impact of the software product manager on the company's vision and business objectives seems to decrease along with the size of the organization.

Roles in the product team also depend on the company size. In micro-enterprises there is a multidisciplinary team of several people with different competences. Responsibility for the product management and all tasks associated with the role of a product manager are handled by the company's founders. Generally there is no strict software product manager position. In small-businesses there is a team of product manager, project manager, UX designer and sometimes other roles like business analyst (B2B). When company grows and becomes a medium business it invests more in the product team and hires even more specialists such as conversion specialist, translation specialist. In large enterprises the roles in the product team depend on the organization structure.

The product characteristics seem also to influence the role of the software product manager at some point. For example, working in the $\mathrm{B} 2 \mathrm{~B}$ model requires negotiations with the client, as well as creating additional documentation specifically for business clients. There are some specific techniques that software product managers in the B2B model use i.e. workshops with clients. On the other side, products in the $\mathrm{B} 2 \mathrm{C}$ model require understanding of the users, their segmentation, source of origin, and their behavior in order to adapt the product to the target group with the highest business potential.

Regarding tools that software product managers use no differences have been identified when we compare business environments, however there are some techniques and tools that can be used only when the number of customers reaches certain point. For example, our research shows that $\mathrm{A} / \mathrm{B}$ testing is not used by product managers in micro-enterprises.

The product lifecycle seems to be very similar in different environments, however there are some exceptions e.g. the standard product lifecycle in B2B companies offering custom solutions for enterprises is affected by tender specification, cost of the evaluation stage, bidding, custom product implementations. In large $\mathrm{B} 2 \mathrm{C}$ companies the product can be created as a result of an internal project or along with the product idea a project can be launched to verify its business value. 


\section{F. Archetype of a software product manager}

Table XII presents the archetype of a software product manager based on the product managers' personas specific to different business environments.

TABLE XII.

ARCHETYPE OF A SOFTWARE PRODUCT MANAGER

\begin{tabular}{|l|l|}
\hline \multicolumn{1}{|c|}{ Attribute } & \multicolumn{1}{c|}{ Description } \\
\hline Objectives & $\begin{array}{l}\text { Achieving goals by implementing the product } \\
\text { strategy and consistent product vision. }\end{array}$ \\
\hline Responsibilities & $\begin{array}{l}\text { Defining goals, proposing solutions, prioritizing } \\
\text { projects or tasks, user research, analysis of } \\
\text { requirements, market analysis, stakeholder } \\
\text { management, cooperation with the development } \\
\text { team. }\end{array}$ \\
\hline $\begin{array}{l}\text { Main } \\
\text { competences }\end{array}$ & $\begin{array}{l}\text { Soft skills: communication, negotiations, } \\
\text { teamwork, decision-making, curiosity of the world, } \\
\text { open-mindedness, assertiveness, understanding of } \\
\text { human behavior, inquisitiveness, networking, } \\
\text { leadership predispositions, consistency and } \\
\text { perseverance. } \\
\text { Hard skills: ability to understand the problem } \\
\text { domain, data analysis and synthesis, knowledge of } \\
\text { business analysis and project management, } \\
\text { interface prototyping, willingness to learn. }\end{array}$ \\
\hline Tools & $\begin{array}{l}\text { Cooperate with all product stakeholders and } \\
\text { development team. }\end{array}$ \\
\hline Cooperation \\
with other teams
\end{tabular}

\section{V.VALIDATION}

The first phase of the validation began on June 7, 2016. It has started by sending an email to 10 experts (the same who participated in the interviews) with a link to the document containing the initial versions of the personas. Until 5 July 2016, the experts expressed their opinions on the personas and suggested changes in their presentation and content. In total, we have received 33 suggestions of corrections and remarks on the misinterpreted or incomplete content. They were all taken into account to build the second version of the personas.

The second phase of the validation took place in 2018 and began on January $25^{\text {th }}$ and ended on February $21^{\text {st }}$. The validation method was the same as in the first phase but this time we engaged new experts who didn't participate in the interviews and the first validation phase. The characteristics of the experts of the second validation phase are presented in Table XIII.

New experts provided 29 remarks in the second validation phase. They did not challenge the personas but rather suggested possible extensions, more competencies, techniques, and tools. The final personas presented in this paper include all the expert's remarks.
TABLE XIII.

CHARACTERISTICS OF EXPERTS IN THE SECOND VALIDATION PHASE

\begin{tabular}{|l|l|l|l|l|}
\hline Identifier & \multicolumn{1}{|c|}{ Position } & Company & \multicolumn{1}{|c|}{ Size } & $\begin{array}{l}\text { Delivery } \\
\text { model }\end{array}$ \\
\hline E11 & $\begin{array}{l}\text { Technical } \\
\text { Product } \\
\text { Manager }\end{array}$ & Dynatrace & large & B2B \\
\hline E12 & $\begin{array}{l}\text { Product } \\
\text { Manager }\end{array}$ & Zalando SE & $\begin{array}{l}\text { medium, } \\
\text { large }\end{array}$ & $\begin{array}{l}\text { B2C, } \\
\text { B2C }\end{array}$ \\
\hline E13 & CEO & Cux.io & micro & B2B \\
\hline E14 & $\begin{array}{l}\text { Senior } \\
\text { Product } \\
\text { Owner }\end{array}$ & STX Net & $\begin{array}{l}\text { micro, } \\
\text { medium, } \\
\text { large }\end{array}$ & $\begin{array}{l}\text { B2B, } \\
\text { B2C, } \\
\text { B2B }\end{array}$ \\
\hline E15 & $\begin{array}{l}\text { Product } \\
\text { Manager }\end{array}$ & Smartly.io & $\begin{array}{l}\text { micro, } \\
\text { medium, } \\
\text { large }\end{array}$ & $\begin{array}{l}\text { B2B, } \\
\text { B2C }\end{array}$ \\
\hline
\end{tabular}

In total, we involved 15 experts who provided input and comments to the proposed personas of software product managers. The coverage of particular business environments with the experts involved in the validation is presented in Table XIV.

TABLE XIV.

NUMBER OF EXPERTS FOR EACH COMPANY SIZE AND DELIVERY MODEL IN THE VALIDATION PHASE

\begin{tabular}{|l|c|c|}
\hline Size / Delivery model & B2B & B2C \\
\hline micro & 4 & 2 \\
\hline small & 2 & 2 \\
\hline medium & 1 & 5 \\
\hline large & 5 & 5 \\
\hline
\end{tabular}

\section{THREATS TO VALIDITY}

\section{A. Threats to construct and internal validity}

We have identified the following threats to the construct and internal validity of our research: (a) interviewer's bias and impact on interviewees, (b) misinterpretation of the interviews with experts, (c) invalid model of the software product manager's persona, (d) subjective construction of the software product manager's archetype.

We have controlled the interviewer's bias and their impact on experts with the semi-closed structured interview design. Each expert was asked the same set of predefined openended questions with no suggested answer. The interviewer was open to further expert's explanations. For details on the interview design see section III of the paper.

The incorrect interpretation of the output from experts was controlled by recording each interview, listening to it several times while extracting data to the personas as well as further validation of the personas with the same experts. Experts verified if the personas correctly represented their statements. For more details on the validation of personas see section $\mathrm{V}$.

Our model of the software product manager's persona covers the aspects of this role we assumed important and worth studying. The technique of a persona allows to use the 
set of attributes which suit the modeling goal. The selected attributes allow for the generalization of the expert's output as well as cover different aspects of the role. More specific aspects can be studied in further research.

We have built the software product manager's archetype using only the data from the personas specific to different business environments. No raw data was added directly to the archetype. We have identified the common elements in all specific personas and put them into the archetype, adding some classification and generalization when appropriate. The archetype was validated by the experts, however it should still be considered a preliminary result of this research. We plan to work on improvements, verification and application of this archetype in the future.

\section{$B$. Threats to external validity}

We have identified the following threats to the external validity of our research: (a) low number of experts, (b) experts selected as a convenience sample, (c) experts sample limited mostly to Polish market.

The first two threats result from the fact that the software product management is a relatively new topic both in research and in practice, therefore access to experienced product managers in IT is naturally limited. We have mitigated these threats by having our experts experienced in several business environments from working in different companies, experiencing the growth of a company (e.g. from small to medium) or working on products with different business models (i.e. both B2B and B2C). As a result, most of the business environments were covered by at least two experts (for details see Tables III and XIV). Furthermore, all experts took part in the first validation phase, where they reviewed all personas, not only those they provided input to. Additional 5 experts from various environment reviewed all personas in the second validation phase, where they mostly proposed some minor extensions (for details see section V).

The experts were identified and contacted with various channels such as personal contacts, business contacts, subscribers and readers of the Product Vision blog [20], and recommendations from identified experts. This method provided for a fairly diverse group of experts with different background and experience (see Tables I and XIII).

We have based our research on data from experts working in the Polish market (apart from one foreign expert involved in the second validation phase). This forms a natural limitation to our current results. The specifics of the product manager's role in different markets, if any, is yet to be investigated. We plan to engage more experts from abroad in our future work.

\section{CONCLUSION}

The aim of this research was to analyze the approach to software product management and the role of the software product manager depending on the size of the organization and the characteristics of the projects.
We have interviewed 10 experts from various IT companies on the role of a software product manager as well as involved a total of 15 experts in the validation of the results. Based on this work we have proposed the personas of a software product manager for 8 different business environments that answer the research question RQ1.

Then we have identified some of the biggest differences between the software product manager's roles in various environments. The key differences are related to the staffing of this role, its scope of responsibility, tools and techniques used as well as the mode of work with the target customers. This partially answers the research question RQ2 and suggests the directions of further research.

Our research also indicated some common elements independent of the area which helped us to create an archetype of the software product manager. The important skills of the product manager are highly developed soft skills, basic hard skills, knowledge of techniques and tools, and empathy towards the customer or user. The product lifecycle seems to be very similar in different environments. The product can be in one of four phases of life and depending on where it is, the product manager must manage its development. In general, the software product manager is responsible for implementing the company's strategy and its business goals. The software product manager's archetype forms the preliminary answer to the research question RQ3.

Additionally, our analysis has revealed the problem of understanding the role of software product manager and common lack of knowledge related to software product management. Interviews with experts have confirmed that people who in fact deal with the software product management may have different job titles (i.e. project manager, function manager, brand manager, product delivery manager), which can result in their lack of awareness of their duties and responsibilities. This may translate later on into making wrong business decisions that have a negative impact on the development of entrepreneurship, companies and products. Also, the relation of the software product manager and the Product Owner and the collaboration of the product manager with agile teams [22], [23] needs further research.

The proposed personas may be used as a guidance and learning targets for software product managers and the toplevel management, where the possible practical applications include: (1) education and training of software product managers both in the industry and academia; (2) selfdevelopment of the current software product managers, in particular seeking to switch the business environment; (3) support for the managers of the organizations planning to hire software product managers or build a software product management team; (4) increasing the awareness and understanding of the software product manager's role by other members of the team and organization. Users can learn on the various details of the software product manager's role from the personas and possibly find their own missing skills, new tools to master or new techniques to apply. 
The research shows that there are many aspects of software product manager's role that require further research: (1) how Software Product Manager interplay with other roles, (2) which roles in the software engineering process have competences to become a software product manager (3) what affects how product teams are structured and how many software product managers are employed.

\section{ACKNOWLEDGMENT}

The authors thank all the experts that took part in the collection of data and the validation of the results.

\section{REFERENCES}

[1] H.-B. Kittlaus, S. A. Fricker, Software Product Management: The ISPMA-Compliant Study Guide and Handbook, Springer, 2017

[2] Ch. Ebert, "The impacts of software product management", Journal of Systems and Software 80 (6), pp. 850-861, 2007, DOI: 10.1016/ j.jss.2006.09.017

[3] T. Tomaszewski: Product Manager vs Project Manager. Available: https://productvision.pl/2013/product-manager-vs-project-manager/

[4] E. Ries, The Lean Startup: How Today's Entrepreneurs Use Continuous Innovation to Create Radically Successful Businesses, Currency, 2011

[5] A. Osterwalder, Y. Pigneur, Business Model Generation: A Handbook for Visionaries, Game Changers, and Challengers, John Wiley and Sons, 2010

[6] Aha.io What tools do product managers use? Available: https:// www.aha.io/roadmapping/guide/product-management/which-tools-doproduct-managers-use

[7] G. Geracie, S. Eppinger: The Guide to the Product Management and Marketing Body of Knowledge: ProdBOK(R) Guide, 2013

[8] A. Maglyas, U. Nikula, K. Smolander, What are the roles of software product managers? An empirical investigation, Journal of Systems and Software 86 (12), 2013, DOI: 10.1016/j.jss.2013.07.045

[9] K. Schwaber, M. Beedle, Agile Software Development with Scrum, Pearson, 2001
[10] H.-B. Kittlaus, Software product management and agile software development: conflicts and solutions. In: Maedche, A., Botzenhardt, A., Neer, L. (eds.) Springer, Berlin, 2012

[11] A. Kaczorowska, Traditional and Agile Project Management in Public Sector and ICT, Proceedings of the 2015 Federated Conference on Computer Science and Information Systems, M. Ganzha, L. Maciaszek, M. Paprzycki (eds). ACSIS, Vol. 5, pages 1521-1531, 2015, DOI: $10.15439 / 2015$ F279

[12] H.-B. Kittlaus, One Size Does Not Fit All: Software Product Management for Speedboats vs. Cruiseships, International conference on software business (ICSOB 2015), Braga, Portugal, 2015

[13] Ch. Ebert, S. Brinkkemper, "Software product management - An industry evaluation", Journal of Systems and Software 95, 2014, DOI: 10.1016/j.jss.2013.12.042

[14] I. van de Weerd, S. Brinkkemper, R. Nieuwenhuis, J. M. Versendaal, A. Bijlsma, On the Creation of a Reference Framework for Software Product Management: Validation and Tool Support, International workshop on software product management (IWSPM'06), Minneapolis, MN, USA, 2006

[15] Pragmatic Marketing, Inc., Pragmatic Marketing Framework, 2016

[16] European Commission, The New SME Definition, User guide and model declaration, 2005

[17] R. Mencarelli, A. de Rivière, "Perceived value in B2B and B2C: A comparative approach and cross-fertilization", Marketing Theory, Vol 15, Issue 2, 2015, DOI: 10.1177/1470593114552581

[18] L. Nielsen, Personas - User Focused Design, Springer, 2013

[19] Definition of archetype, Merriam-Webster Dictionary, https:// www.merriam-webster.com/dictionary/archetype

[20] Product Crew, Product Vision Blog, www.productvision.pl

[21] A. Strauss, J. Corbin, Basics of Qualitative Research - Techniques and Procedures for Developing Grounded Theory, second edition, Sage Publications, London, 1998

[22] A. Przybyłek, M. Zakrzewski, Adopting Collaborative Games into Agile Requirements Engineering, 13th International Conference on Evaluation of Novel Approaches to Software Engineering (ENASE'18), Funchal, Madeira, Portugal, 2018

[23] A. Przybyłek, D. Kotecka, Making agile retrospectives more awesome, Proceedings of the 2017 Federated Conference on Computer Science and Information Systems, M. Ganzha, L. Maciaszek, M. Paprzycki (eds), ACSIS, Vol. 11, pp. 1211-1216, 2017, DOI: $10.15439 / 2017 \mathrm{~F} 423$ 